\title{
Peningkatan Kematangan Proses TI: Penilaian, Rekomendasi dan Validasi (Studi Kasus Sistem Informasi IPOS)
}

\author{
Setiyowati $^{1)}$, Sri Siswanti' ${ }^{2)}$, Andriani Kusumaningrum ${ }^{3)}$, Kumaratih Sandradewi ${ }^{4)}$ \\ ${ }^{1)}$ Program Studi Manajemen Informatika, STMIK Sinar Nusantara \\ ${ }^{2)}$ Program Studi Teknik Informatika, STMIK Sinar Nusantara \\ ${ }^{3,4)}$ Program Studi Komputerisasi Akuntansi, STMIK Sinar Nusantara \\ ${ }^{1)}$ setivowati@sinus.ac.id, ${ }^{2}$ syswanty@sinus.ac.id, ${ }^{3)}$ andriani@ sinus.ac.id, ${ }^{4)}$ kumaratih@ sinus.ac.id
}

\begin{abstract}
IPOS information system is a service delivery system (package) and letter (mail) PT Pos Indonesia. The application of the IPOS information system still found problems, the problem of human resources, bar codes that were not in accordance with the delivery receipt. So it is necessary to do an assessment of the IPOS information system, the purpose of this study is to determine the level of maturity of the system information, formulate recommendations for improvements if needed and validation recommendations. The framework used assessment is COBIT 4.1 framework, focus DS10 process (Managing Problems) and DS11 (Managing Data). The results of the assessment will be obtained maturity level, then the formulation of recommendations for increasing maturity is carried out, then validation of the recommendations proposed. Data collection techniques with observation, interviews, study of business documents, literature studies, and questionnaires. Data is processed based on COBIT framework rules 4.1. The results of the DS10 and DS11 process assessments are at Level 3 (Defined), management has been managed well but its implementation is still not maximal. Recommended improvements to DS10 and DS11 as 3 recomendation. The results of the recommendation validation are in the score 4 to 6 , is capable with great effort

Keywords : IPOS information system, Framework COBIT 4.1, Maturity Level.
\end{abstract}

\section{PENDAHULUAN}

Peranan teknologi informasi tidak lepas dalam kegiatan operasional pada PT Pos Indonesia, salah satunya adalah sistem informasi IPOS, IPOS digunakan untuk sistem layanan jasa pengiriman barang (package) serta surat (mail).

Berdasarkan hasil observasi dan wawancara pada manajemen dalam sistem layanan IPOS didapatkan informasi bahwa sistem sudah dikelola baik, namun pada kenyataannya masih ditemukan beberapa masalah yang timbul antara lain masalah sumber daya manusia (human problems), serta permasalahan yang berkaitan dengan pengelolaan data seperti data barkode yang tidak sesuai dengan resi pengiriman, data yang masih belum update dari server secara otomatis. Sehingga diperlukan suatu penilaian terhadap sistem informasi IPOS tersebut.

Diperlukan adanya perencanaan model tata kelola pada penerapan sistem informasi IPOS, sehingga dalam penerapan IPOS dapat berjalan secara sistematis terkendali dan efektif. Sebuah framework yang bisa digunakan untuk menyusun tata kelola TI maupun melaksanakan audit TI yang telah diakui secara internasional salah satunya adalah COBIT (Control Objectives for Information and related Technology). Menurut (IT Governance Institute, 2007), COBIT mempunyai kompromi antar dimensi detail atau kedalaman standar dalam hal teknis dan operasional serta kelengkapan proses TI yang lebih baik dibanding standar tata kelola lain COBIT juga mempunyai spektrum proses TI yang lebih luas dan lebih detail.

Tujuan penelitian adalah untuk mengetahui tingkat kematangan (maturity level) sistem yang saat ini berjalan, mengetahui tingkat kematangan yang diharapkan, merumuskan 
rekomendasi perbaikan jika diperlukan serta melakukan validasi rekomendasi apakah rekomendasi yang diusulkan bisa diterapkan pada organisasi yang menjadi objek penelitian.

\section{TINJAUAN PUSTAKA}

Penelitian ini merujuk pada proses COBIT 4.1 dan model kematangan. Cobit 4.1 memiliki kerangka kerja dan standar tata kelola dengan cakupan yang luas. COBIT 4.1 terdiri dari 34 proses yang dikelompokkan dalam empat domain, yaitu plan and organise (PO), acquire and implement (AI), deliver and support (DS), dan monitor and evaluate (ME). Suatu proses mencakup sejumlah tujuan kontrol, yaitu serangkaian persyaratan tingkat tinggi untuk pengendalian proses yang efektif. Tujuan pengendalian dapat berupa struktur, kebijakan, dan prosedur organisasi (Iqbal \& Nieves, 2007).

Semua proses pada Cobit 4.1 memiliki atribut yang sama, masing-masing atribut mewakili aspek dari suatu proses. Atribut yang digunakan terdiri dari enam yaitu (a) awareness and communication; (b) policies, plans and procedures; (c) tools and automation; (d) skill and expertise; (e) responsibility and accountability; dan (f) goal setting and measurement. Atribut-atribut tersebut digunakan untuk menilai kematangan suatu proses, sehingga disebut dengan maturity attributes (Iqbal \& Nieves, 2007).

Atribut awareness and communication (AC) dari suatu proses menunjukkan apakah perusahaan sepenuhnya memahami akan pentingnya proses itu dan apakah manajemen mengkomunikasikan masalah ini dengan menggunakan teknik komunikasi yang matang. Atribut policies, plans and procedures (PPP) menunjukkan apakah proses yang berjalan sudah baik dan lengkap, yaitu semua kebijakan terkait disetujui, dan prosedur diadopsi, diikuti, dan didokumentasikan. Atribut tools and automation (TA) menunjukkan apakah perusahaan mengimplementasikan alat yang telah terstandarisasi untuk mengotomatisasi dan memantau proses. Atribut skill and expertise (SE) menunjukkan apakah perusahaan memperbarui keterampilan yang diperlukan untuk proses tersebut, yang mencakup rencana pelatihan, sertifikasi, dan berbagi pengetahuan. Atribut responsibility and accountability (RA) menunjukkan apakah tanggung jawab dan akuntabilitas proses didefinisikan dengan jelas dan apakah budaya reward digunakan untuk memotivasi tindakan positif terhadap proses tersebut. Atribut yang terakhir, goal setting and measurement (GSM) menunjukkan apakah perusahaan mengukur efektivitas dan efisiensi proses serta menghubungkan hasilnya dengan tujuan strategis bisnis organisasi (Iqbal \& Nieves, 2007).

Kematangan suatu proses berevolusi dari tidak ada menjadi proses yang dioptimalkan. COBIT menyediakan model kematangan dari setiap proses serta mengadaptasinya untuk menentukan model kematangan yang lebih spesifik. Tabel 1 menunjukkan model kematangan proses DS10, dan Tabel 2 menunjukkan model kematangan proses DS11(Iqbal \& Nieves, 2007).

Tabel 1. Maturity model of process DS10 (Iqbal \& Nieves, 2007)

\begin{tabular}{|c|l|l|}
\hline Level & \multicolumn{1}{|c|}{ Status } & \multicolumn{1}{c|}{ Description } \\
\hline 0 & Non-existent & $\begin{array}{l}\text { Organisasi tidak ada kesadaran akan perlunya dalam mengelola masalah, karena } \\
\text { tidak ada perbedaan masalah dan insiden. Oleh karena itu, tidak ada upaya yang } \\
\text { dilakukan untuk mengidentifikasikan akar permasalahan yang menjadi penyebab } \\
\text { terjadinya insiden. }\end{array}$ \\
\hline 1 & Initial/ad hoc & $\begin{array}{l}\text { Personil sudah mengenali kebutuhan akan pentingnya mengelola masalah dan } \\
\text { bagaimana menyelesaikan permasalahan dan mencari penyebab yang } \\
\text { mendasarinya. Personel yang memiliki pengetahuan sesuai dengan bidang } \\
\text { keahliannya memberikan bantuan dalam menyelesaikan masalah sesuai bidang }\end{array}$ \\
\hline
\end{tabular}


Tabel 2. Lanjutan Maturity model of process DS10 (Iqbal \& Nieves, 2007)

\begin{tabular}{|c|c|c|}
\hline Level & Status & Description \\
\hline & & $\begin{array}{l}\text { keahlian mereka, akan tetapi tanggung jawab untuk manajemen masalah tidak } \\
\text { ada yang ditunjuk. Jika Informasi yang bersifat penting tidak dibagikan sehingga } \\
\text { menimbulkan masalah baru yang berakibat pada hilangnya waktu produktif. }\end{array}$ \\
\hline 2 & $\begin{array}{l}\text { Repeatable but } \\
\text { intuitive }\end{array}$ & $\begin{array}{l}\text { Organisasi ada kesadaran yang tinggi tentang kebutuhan dan manfaat mengelola } \\
\text { masalah TI di dalam unit bisnis dan fungsi layanan informasi. Proses } \\
\text { penyelesaian dikembangkan ke titik di mana beberapa individu kunci } \\
\text { bertanggung jawab untuk mengidentifikasikan dan menyelesaikan masalah. } \\
\text { Informasi dibagikan ke staf dengan cara informal dan reaktif. Tingkat layanan } \\
\text { untuk komunitas pengguna bervariasi dan terhambat oleh kurangnya } \\
\text { pengetahuan terstruktur yang tersedia untuk pengelola masalah. }\end{array}$ \\
\hline 3 & Defined & $\begin{array}{l}\text { Organisasi sudah mengetahui kebutuhan akan sistem manajemen masalah yang } \\
\text { terintegrasi dan efektif, dibuktikan dengan adanya dukungan manajemen berupa } \\
\text { anggaran untuk pelatihan pegawai. Resolusi masalah dan proses eskalasi telah } \\
\text { distandarisasi. Rekaman, pelacakan masalah serta tuntutan mereka dipecah } \\
\text { mencadi beberapa bagian dan dibentuk tim untuk memberi respon, } \\
\text { menggunakan alat yang tersedia tanpa sentralisasi. Penyimpangan dari norma } \\
\text { atau standar yang ditetapkan cenderung tidak terdeteksi. Informasi dibagikan } \\
\text { kepada staf secara proaktif dan formal. Tinjauan manajemen atas insiden serta } \\
\text { analisis identifikasi penyelesaian masalah terbatas dan informal. }\end{array}$ \\
\hline 4 & $\begin{array}{l}\text { Managed and } \\
\text { measurable }\end{array}$ & $\begin{array}{l}\text { Proses manajemen masalah sudah dipahami di semua tingkatan dalam } \\
\text { organisasi. Tanggung jawab dan kepemilikan jelas dan mapan. Metode dan } \\
\text { prosedur sudah didokumentasikan, dikomunikasikan dan diukur untuk } \\
\text { efektivitas. Mayoritas masalah sudah dilakukan diidentifikasi, dicatat dan } \\
\text { dilaporkan, serta kapan penyelesaiannya dimulai. Pengetahuan dan keahlian } \\
\text { dipelihara dan dikembangkan untuk tingkat yang lebih tinggi, karena fungsinya } \\
\text { dipandang sebagai aset dan kontributor utama dalam pencapaian tujuan TI dan } \\
\text { peningkatan layanan TI. Manajemen masalah yang terintegrasi dengan baik } \\
\text { disertai proses yang saling terkait, seperti insiden, perubahan, ketersediaan dan } \\
\text { manajemen konfigurasi, dan membantu pelanggan dalam mengelola data, } \\
\text { fasilitas, dan operasi. Sasaran dan metrik telah disetujui untuk proses manajemen } \\
\text { masalah. }\end{array}$ \\
\hline 5 & Optimised & $\begin{array}{l}\text { Proses manajemen masalah berkembang menjadi proses yang berwawasan ke } \\
\text { depan dan proaktif, memiliki kontribusi pada tujuan TI. Masalah yang timbul } \\
\text { dapat diantisipasi dan dicegah. Pengetahuan tentang pola masalah yang telah lalu } \\
\text { dan yang akan datang dipertahankan melalui kontak rutin dengan vendor dan } \\
\text { pakar. Rekaman, pelaporan, dan analisis masalah dan resolusi sudah } \\
\text { diautomatisasi dan sepenuhnya terintegrasi dengan manajemen konfigurasi data. } \\
\text { Tujuan diukur secara konsisten. Sebagian besar sistem telah dilengkapi dengan } \\
\text { mekanisme untuk mendeteksi dan memberikan peringatan secara otomatis, yang } \\
\text { secara terus-menerus dilacak dan dievaluasi. Proses manajemen masalah } \\
\text { dianalisis untuk perbaikan yang berkelanjutan berdasarkan analisis tindakan dan } \\
\text { dilaporkan kepada para pemangku kepentingan. }\end{array}$ \\
\hline
\end{tabular}

Tabel 3. Maturity model of process DS11 (Iqbal \& Nieves, 2007)

\begin{tabular}{|c|l|l|}
\hline Level & Status & \multicolumn{1}{|c|}{ Description } \\
\hline 0 & Non-existent & $\begin{array}{l}\text { Data tidak diakui sebagai sumber daya dan aset perusahaan. Tidak ada kepemilikan } \\
\text { data, karena organisasi tidak menunjuk personil yang ditugaskan atau } \\
\text { pertanggungjawaban untuk pengelolaan data. Kualitas dan keamanan data buruk atau } \\
\text { tidak ada. }\end{array}$ \\
\hline 1 & $\begin{array}{l}\text { Initial/ad } \\
\text { hoc }\end{array}$ & $\begin{array}{l}\text { Organisasi mengakui akan kebutuhan manajemen data yang baik. Ada pendekatan ad } \\
\text { hoc dalam menentukan persyaratan keamanan untuk manajemen data, tetapi tidak ada } \\
\text { prosedur komunikasi formal yang tersedia. Tidak ada pelatihan khusus tentang } \\
\text { manajemen data. Tanggung jawab untuk manajemen data tidak jelas. Prosedur untuk } \\
\text { mengatur dalam melakukan backup/ restore dan delete belum tersedia. }\end{array}$ \\
\hline
\end{tabular}


Tabel 4. Lanjutan Maturity model of process DS11 (Iqbal \& Nieves, 2007)

\begin{tabular}{|c|c|c|}
\hline Level & Status & Description \\
\hline 2 & $\begin{array}{l}\text { Repeatable but } \\
\text { intuitive }\end{array}$ & $\begin{array}{l}\text { Organisasi sudah memiliki kesadaran akan perlunya manajemen data yang } \\
\text { efektif. Kepemilikan data di level atas sudah mulai dilakukan. Persyaratan } \\
\text { keamanan untuk manajemen data telah didokumentasikan oleh individu } \\
\text { kunci. Beberapa pemantauan dalam TI dilakukan hanya pada kegiatan } \\
\text { pengelolaan data utama (misal: Backup, restore, dan delete). Tanggung jawab } \\
\text { untuk pengelolaan data bersifat informal hanya ditugaskan untuk anggota staf } \\
\text { utama TI. }\end{array}$ \\
\hline 3 & Defined & $\begin{array}{l}\text { Organisasi sudah memahami akan kebutuhan akan manajemen data TI. } \\
\text { Membentuk penanggung jawab pengelola data. Kepemilikan data diberikan } \\
\text { kepada pihak yang bertanggung jawab yang mengontrol integritas dan } \\
\text { keamanan Data, memformalkan prosedur dalam pengelolaan TI, serta } \\
\text { penggunaan peralatan untuk backup, restore dan delete. Dilakukan } \\
\text { pemantauan dalam manajemen data. Matrik kinerja dasar didefinisikan. } \\
\text { Memberikan Pelatihan kepada staf dan anggota dalam manajemen data. }\end{array}$ \\
\hline 4 & $\begin{array}{l}\text { Managed and } \\
\text { measurable }\end{array}$ & $\begin{array}{l}\text { Organisasi sudah memahami akan kebutuhan manajemen data serta tindakan } \\
\text { yang diperlukan. Tanggung jawab atas data kepemilikan dan manajemen } \\
\text { sudah didefinisikan dengan jelas, ditugaskan dan dikomunikasikan dalam } \\
\text { organisasi. Prosedur diformalkan dan disosialisasikan secara luas. } \\
\text { Penggunaan tools mulai diterapkan. Indikator sasaran dan kinerja disepakati } \\
\text { dengan pelanggan dan dimonitoring melalui proses yang jelas. Pelatihan } \\
\text { formal untuk anggota staf manajemen data sudah tersedia. }\end{array}$ \\
\hline 5 & Optimised & $\begin{array}{l}\text { Kebutuhan akan manajemen data dan pemahaman tentang semua tindakan } \\
\text { yang diperlukan dipahami dan diterima di dalam organisasi. Kebutuhan dan } \\
\text { persyaratan yang dibutuhkan untuk kebutuhan yang akan datang dieksplorasi } \\
\text { secara proaktif. Tanggung jawab untuk kepemilikan data dan manajemen data } \\
\text { secara jelas dibuat, diinformasikan dan disosialisasikan ke seluruh organisasi } \\
\text { dan diperbarui tepat waktu. Prosedur diformalkan dan disosialisasikan, } \\
\text { berbagi pengetahuan adalah praktik standar. Alat canggih digunakan dengan } \\
\text { otomatisasi data dikelola dengan maksimal. Indikator sasaran dan kinerja } \\
\text { disepakati dengan pelanggan, terkait dengan tujuan bisnis dan secara } \\
\text { konsisten dimonitoring menggunakan proses yang terdefinisi dengan baik. } \\
\text { Peluang untuk perbaikan terus dieksplorasi. Pelatihan untuk manajemen data } \\
\text { anggota staf dikembagakan. }\end{array}$ \\
\hline
\end{tabular}

Maturity level adalah suatu cara untuk mengukur bagaimana suatu proses manajemen telah dilakukan. Secara umum, maturity level berguna untuk memampukan perusahaan melakukan branch marking dan identifikasi pembaharuan yang dilakukan. Pada COBIT terdapat enam level penilaian seperti pada Tabel 1 dan Tabel 2.

Pengukuran tingkat kematangan yang dirumuskan berdasarkan formulasi nilai kematangan Detail Control Objective (CO) hingga mendapatkan nilai akhir yang menjelaskan tentang kondisi yang terjadi. Aturan rumusan tingkat kematangan telah diatur sebelumnya dengan standar skala maturity level COBIT 4.1. Tabel 3 adalah Skala dari tingkat indeks kematangan pada COBIT. (Iqbal \& Nieves, 2007).

Tabel 5.. Skala Indeks Tingkat Kematangan COBIT (ITGI, 2007)

\begin{tabular}{|l|c|}
\hline \multicolumn{1}{|c|}{ Tingkat Kematangan } & Skala Pengukuran \\
\hline Skala 0 - Non Existent & $0,00-0,50$ \\
\hline Skala 1 - Initial / Ad Hoc & $0,51-1,50$ \\
\hline Skala 2 - Repeatable but Intuitive & $1,51-2,50$ \\
\hline Skala 3 - Defined & $2,51-3,50$ \\
\hline Skala 4- Managed and Measurable & $3,51-4,50$ \\
\hline Skala 5 - Optimised & $4,51-5,00$ \\
\hline
\end{tabular}


Beberapa metode penilaian untuk kematangan proses TI telah ditetapkan (Pederiva, 2003), (Wijkström, 2007), (Walker, McBride, Basson, \& Oakley, 2012), (Dirgahayu \& Setiyowati, 2018). Namun metode tersebut tidak mempertimbangkan atribut kematangan dengan cara yang tepat dan komprehensif. Oleh karena itu, metode untuk menilai kematangan proses TI berdasarkan atribut proses dan Control Objective diusulkan untuk menyelesaikan penelitian ini (Gomes \& Ribeiro, 2009), (Tanuwijaya \& Sarno, 2010), (Dirgahayu \& Setiyowati, 2018).

Penelitian yang dilakukan oleh Teduh Dirgahayu dan Setiyowati dengan judul On the Improvement of IT process maturity: assessment, recommendation and validation: MATEC Web of Conferences 154, 03017 (2018), yaitu penerapan E-KTP di sebuah Kabupaten di wilayah Jawa Tengah, dengan fokus pada Control Objective DS7.1, DS7.2, dan DS7.3. Hasil penelitian ini adalah berupa rekomendasi dan validasi rekomendasi, hasil penelitian menunjukkan bahwa tingkat kematangan DS7 adalah 2.13 yaitu pada level 2 . Rekomendasi yang diberikan berdasarkan Cobit 4.1 adalah Procedures to use tools systematically shall be defined dan performance indicators shall be defined, hasil validasi menunjukkan bahwa organisasi dapat menerapkan rekomendasi Procedures to use tools systematically shall be defined pada angka 7 yaitu Capable with great efforts sedangkan rekomendasi performance indicators shall be defined pada angka 2 yaitu Not Capable (Dirgahayu \& Setiyowati, 2018),(Fitrianah \& Sucahyo, 2008).

\section{METODE PENELITIAN}

a. Metode PengambilanData

Pengambilan data pada penelitian ini, adalah pengambilan data secara langsung (data primer) dan tidak langsung (data sekunder). Data primer diperoleh dengan mengamati kondisi sistem yang sedang berjalan, yaitu dengan melakukan seperti wawancara, dan observasi. Data sekunder diperoleh dari studi pustaka serta literature lain seperti dokumen bisnis dan penelitian yang telah dilakukan sebelumnya.

\section{b. Metode Pengolahan Data}

Pengolahan data dengan menggunakan kuisioner yang diberikan kepada responden yang telah ditentukan sesuai tabel RACI pada Cobit 4.1. (IT Governance Institute, 2003), (IT Governance Institute, 2007). Responden dalam penelitian ini adalah orang yang menggunakan atau mengelola operasional pada sistem informasi tersebut.

\section{c. Analis Tingkat Kematangan saat ini (as-is)}

Rumus (1) digunakan untuk perhitungan tingkat kematangan saat ini sesuai atribut COBIT 4.1.. (Dirgahayu \& Setiyowati, 2018).

$$
\begin{aligned}
& X i=\frac{\sum X n}{\sum r} \\
& \text { Keterangan : } \mathrm{X}_{1}=\text { nıla kematangan atribut } \\
& \sum X a=\text { jumlah nilai tiap atribut } \\
& \sum r \quad=\text { jumlah responden }
\end{aligned}
$$

Rumus yang diguankan untuk menghitung nilai kematangan control objective seperti pada rumus (2). (Dirgahayu \& Setiyowati, 2018)

$$
X_{C O}=\frac{\sum_{6}^{n} X i}{6}
$$


Keterangan :

$X_{c o} \quad=$ nilai tingkat kematangan $\mathrm{CO}$

$\sum X i=$ nilai kematangan atribut

$6=$ jumlah atribut

\section{d. Rekomendasi}

Rekomendasi bertujuan untuk memberikan gambaran perbaikan yang dibutuhkan perusahaan berdasarkan hasil data yang diperoleh. Rekomendasi berdasarkan hasil dari pemetaan tingkat kematangan COBIT 4.1.

\section{e. Validasi rekomendasi}

Validasi rekomendasi ini dilakukan untuk mengetahui apakah rekomendasi yang telah dirumuskan bisa diterapkan pada organisasi tersebut atau tidak.

\section{HASIL DAN PEMBAHASAN}

\subsection{Studi kasus}

Penelitian ini dilakukan di PT. Pos Indonesia, dengan studi kasus pada sebuah Kabupaten di Jawa Tengah. Untuk menilai tingkat kematangan proses, peneliti membagikan kuesioner kepada orang-orang yang bertanggung jawab terhadap sistem informasi IPOS yaitu Manajer Proses Transportasi Antaran, Manajer Pelayanan Luar dan Agen, Manajer SDM IT dan Sarana, Manajer Pelayanan Surat dan Paket Auditor Internal, petugas Loket, Kepala Kantor Pos Cabang (KKPC). Selain dengan kuisioner, peneliti juga melakukan pengamatan terhadap praktek penggunaan IPOS dan melakukan Tanya jawab kepada responden mengenai harapan yang diinginkan terkait sistem IPOS yang saat ini berjalan. Hasil kuisioner tersebut dihitung dan dianalisis.

Berdasarkan tingkat kematangan saat ini (as is) yang diperoleh serta tingkat kematangan yang diharapkan (to be), apabila terjadi kesenjangan, maka dilakukan perumusan rekomendasi perbaikan untuk peningkatan kematangan proses DS10 dan DS 11 dengan merujuk pada praktek framework Cobit. Kemudian rekomendasi tersebut selanjutnya dilakukan validasi rekomendasi dengan melakukan konfirmasi kepada orangorang yang memiliki wewenang untuk menjalankan rekomendasi tersebut yaitu Kepala Kantor Cabang dan Menejer SDM IT. Apabila Devisi tersebut tidak mampu mengimplementasikan rekomendasi yang diberikan dengan tepat, tahap selanjutnya adalah melakukan tanya jawab mengenai kendala apa yang dihadapi.

Penelitian ini fokus pada Proses DS10 (Manage Problems) dan DS11 (Manage Data), proses tersebut dipilih karena adanya masalah yang tibul dari praktek penggunaan Sistem Informasi IPOS, guna memberikan penilaian terhadap manajemen pengelolaan masalah dan manajemen data. Penelitian ini berfokus pada pendekatan penilaian kematangan proses TI, rekomendasi, dan validasi. Penelitian ini tidak memberikan deskripsi secara lengkap dan terperinci tentang bagaimana penerapkan pendekatan tersebut dalam studi kasus ini.

\subsection{Maturity Assessment}

IT proses pada Cobit 4.1 terdiri dari control process dan avtivities (IT Governance Institute, 2007). Control objectives adalah persyaratan yang harus dipenuhi oleh proses, sedangkan activities adalah sarana untuk memenuhi control objectives (Dirgahayu \& Setiyowati, 2018), (Wijkström, 2007), (Wijkström, 2007), (Gui, Gondodiyoto, \& Japari, 
2010), (Terttiaavini, 2013). Pada tabel 4 berikut ini adalah hasil penilaian kematangan Proses D10, sedangkan Tabel 5, adalah hasil penilaian kematangan Proses DS11.

Tabel 6.. Kematangan Proses DS10

\begin{tabular}{|c|c|c|c|c|c|c|c|c|c|}
\hline \multirow{2}{*}{$\mathrm{CO}$} & \multicolumn{6}{|c|}{ Maturity attributes } & \multirow{2}{*}{ CO Maturity } & \multirow{2}{*}{$\begin{array}{c}\text { Rata-rata } \\
\text { CO }\end{array}$} & \multirow{2}{*}{$\begin{array}{l}\text { IT Process } \\
\text { Maturity }\end{array}$} \\
\hline & $\mathrm{AC}$ & PPP & TA & $\mathrm{SE}$ & RA & GSM & & & \\
\hline DS10.1 & 2.67 & 2.73 & 3 & 3.13 & 2.87 & 3.07 & 2,91 & \multirow{4}{*}{2.95} & \multirow{4}{*}{ Level 3} \\
\hline DS10.2 & 2,93 & 2,67 & 2,93 & 2,87 & 2,47 & 2,87 & 2,79 & & \\
\hline DS10.3 & 2,87 & 2,60 & 2,87 & 3,27 & 2,67 & 3,20 & 2.91 & & \\
\hline DS10.4 & 2,93 & 2,67 & 2,53 & 2,73 & 2,87 & 3,20 & 2,82 & & \\
\hline
\end{tabular}

Tabel 7. Kematangan Proses DS11

\begin{tabular}{|c|c|c|c|c|c|c|c|c|c|}
\hline \multirow{2}{*}{$\mathrm{CO}$} & \multicolumn{6}{|c|}{ Maturity attributes } & \multirow{2}{*}{$\begin{array}{c}\mathrm{CO} \\
\text { Maturity }\end{array}$} & \multirow{2}{*}{$\begin{array}{c}\text { Rata-rata } \\
\text { CO }\end{array}$} & \multirow{2}{*}{$\begin{array}{c}\text { IT Process } \\
\text { Maturity }\end{array}$} \\
\hline & $\mathrm{AC}$ & PPP & TA & SE & RA & GSM & & & \\
\hline DS11.1 & 3,53 & 3,47 & 3,67 & 3,07 & 3,13 & 3,20 & 3,34 & \multirow{6}{*}{3.27} & \multirow{6}{*}{ Level 3} \\
\hline DS11.2 & 3,33 & 2,93 & 3,40 & 2,93 & 2,93 & 3,27 & 3,13 & & \\
\hline DS11.3 & 3,27 & 2,93 & 3,47 & 3,13 & 2,93 & 3,20 & 3,16 & & \\
\hline DS11.4 & 3,27 & 3,20 & 3,60 & 3,27 & 3,07 & 3,13 & 3,26 & & \\
\hline DS11.5 & 3,47 & 3,40 & 3,60 & 3,20 & 3,27 & 3,33 & 3,38 & & \\
\hline DS11.6 & 3,60 & 3,20 & 3,60 & 3,27 & 3,07 & 3,40 & 3,36 & & \\
\hline
\end{tabular}

Tabel 8. Rekomendasi Proses DS10

\begin{tabular}{|c|c|c|c|}
\hline $\mathrm{CO}$ & Current practices & $\begin{array}{c}\text { Actions for } \\
\text { improvement }\end{array}$ & $\begin{array}{c}\text { Recommendation for } \\
\text { management }\end{array}$ \\
\hline DS10.1 & $\begin{array}{l}\text { Standar prosedur yang digunakan } \\
\text { dalam melakukanidentifikasi dan } \\
\text { klasifikasi masalah masih belum } \\
\text { dilakukan dengan baik oleh masing- } \\
\text { masing individual, sehingga apabila } \\
\text { timbul masalah, maka yang terjadi } \\
\text { adalah sering terabaikan. }\end{array}$ & \multirow[t]{3}{*}{$\begin{array}{l}\text { Memberikan sosialisasi } \\
\text { dan pemahaman akan } \\
\text { pentingnya Menjalankan } \\
\text { kebijakan Standar } \\
\text { Prosedur secara kontinyu }\end{array}$} & \multirow{3}{*}{$\begin{array}{l}\text { Adanya standar } \\
\text { kebijakan untuk } \\
\text { mempermudah dalam } \\
\text { melakukan prosedur } \\
\text { pengelolaan masalah } \\
\text { sehingga instansi harus } \\
\text { menetapkan pihak } \\
\text { penanggungjawab } \\
\text { dengan berdasarkan } \\
\text { standar dan kebijakan } \\
\text { tersebut dapat disertai } \\
\text { reward \& punishment } \\
\text { terhadap penanganan } \\
\text { insiden. }\end{array}$} \\
\hline DS10.2 & $\begin{array}{l}\text { Prosedur dalam pelacakan masalah } \\
\text { dilakukan hanya sebatas pada saat } \\
\text { terjadi masalah } \\
\text { memungkinkan akan } r \text { terjadi } \\
\text { penerapan solusi yang berbeda } \\
\text { dikemudian hari. }\end{array}$ & & \\
\hline DS10.3 & $\begin{array}{lrr}\text { Standar kebijakan } & \text { dalam } \\
\text { penyelesaian masalah masih } & \text { man } \\
\text { dilakukan secara bertahap sehingga } \\
\text { dalam penutupan masalah } \\
\text { membutuhkan waktu yang cukup } \\
\text { lama. }\end{array}$ & & \\
\hline DS10.4 & $\begin{array}{l}\text { Standar prosedur yang digunakan } \\
\text { dalam melakukanidentifikasi dan } \\
\text { klasifikasi masalah masih belum } \\
\text { dilakukan dengan baik oleh masing- } \\
\text { masing individual, sehingga apabila } \\
\text { timbul masalah, maka yang terjadi } \\
\text { adalah sering terabaikan. }\end{array}$ & $\begin{array}{lr}\text { Membentuk Tim/ unit/ } \\
\text { individu } & \text { sebagai } \\
\text { penanggung jawab untuk } \\
\text { memonitoring } \\
\text { evaluasi dan } \\
\text { berjalannya } \\
\text { standar prosedur dengadap } \\
\text { baik }\end{array}$ & $\begin{array}{l}\text { Instansi } \\
\text { menetapkan } \\
\text { penanggungjawab dalam } \\
\text { pelaporan manajemen } \\
\text { masalah secara formal } \\
\text { untuk memudahkan } \\
\text { aktivitas monitoring dan } \\
\text { proses evaluasi kondisi } \\
\text { perusahaan. }\end{array}$ \\
\hline
\end{tabular}


Tabel 9. Rekomendasi Proses DS11

\begin{tabular}{|c|c|c|c|}
\hline $\mathrm{CO}$ & Current practices & $\begin{array}{c}\text { Actions for } \\
\text { improvement }\end{array}$ & $\begin{array}{l}\text { Recommendation for } \\
\text { management }\end{array}$ \\
\hline $\begin{array}{l}\text { DS11.1 } \\
\text { DS11.2 } \\
\text { DS11.3 } \\
\text { DS11.4 } \\
\text { DS11.5 } \\
\text { DS } 11.6\end{array}$ & $\begin{array}{l}\text { Kebijakan dan prosedur } \\
\text { dalam pelaksanaan } \\
\text { pengelolaan, pemeliharaan } \\
\text { serta keamanan data masih } \\
\text { dilakukan bertahap serta } \\
\text { belum diterapkan secara } \\
\text { formal. }\end{array}$ & $\begin{array}{l}\text { Memformalkan } \\
\text { kebijakan dan } \\
\text { prosedur, kemudian } \\
\text { memberikan sosialisasi } \\
\text { tentang adanya } \\
\text { kebijakan dan prosedur } \\
\text { pengelolaan, } \\
\text { pemeliharaan } \\
\text { keamanan data }\end{array}$ & $\begin{array}{l}\text { Instansi harus menetapkan } \\
\text { kebijakan dan prosedur manajemen } \\
\text { data yang formal seperti aturan } \\
\text { khusus / SOP dimana ketetapan } \\
\text { aturan tersebut dapat diterima oleh } \\
\text { seluruh divisi dan berorientasi pada } \\
\text { kondisi sistem pelayanan dimasa } \\
\text { depan yang lebih baik. }\end{array}$ \\
\hline
\end{tabular}

Tahap penilaian dimulai dengan melihat fokus area yaitu pada proses DS10 (Manage Problems) dan DS11 (Manage Data). Selanjutnya pembuatan kuesioner berdasarkan RACI Chart untuk masing-masing proses, dengan jumlah responden berkaitan dengan manajemen masalah sebanyak 15 responden, sedangkan berkaitan dengan manajemen data sebanyak 15 responden.

Berdasarkan nilai kinerja dari kuesioner yang telah disebar, maka akan diformulasi dengan analisa nilai kematangan atribut dan Control Objective (CO).

\subsection{Analisa Nilai Kematangan Atribut}

$$
X i=\frac{\sum X n}{\sum r}
$$

Keterangan :

$X_{i} \quad=$ Nilai rata-rata kematangan atribut COBIT

$\sum X n=$ Jumlah nilai atribut tiap Detail of Control Objective (DCO)

$\sum R=$ Jumlah Responden

\subsection{Analisa Tingkat Kematangan Control Objective (CO)}

$$
X_{C O}=\frac{\sum_{6}^{n} X i}{6}
$$

Keterangan : $X_{C O}=$ Nilai rata-rata tingkat kematangan DCO COBIT $\sum X_{i}=$ Jumlah nilai rata-rata kematangan atribut COBIT $6=$ Jumlah atribut COBIT 4.1

Hasil penghitungan nilai kematangan untuk masing-masing Control Objective seperti pada Tabel 4 dan Tabel 5.

Berdasarkan hasil perhitungan nilai kematangan seperti pada Tabel 4 dan Tabel 5, diperoleh tingkat pemenuhan $\mathrm{CO}$ pada pengelolaan masalah mendekati nilai baik dengan rata-rata nilai kematangan DS10 yaitu sebesar 2,95 berada pada level 3. Sedangkan DS 11 pada nilai rata-rata 3.27. Nilai tersebut menunjukkan pada tingkat kematangan 3 (Defined).

\subsection{Rekomendasi}

Hasil penelitian bahwa tingkat kematangan yang diharapkan (to be) pada level 4 (dikelola dan terukur). Sedangkan hasil penghitungan nilai kematangan yaitu pada level 3 
sehingga ada kesenjangan antara kematangan saat ini dan kematangan harapan, maka diperlukan adanya tindakan dan rekomendasi untuk meningkatkan kematangan proses TI. Dari hasil penilaian tersebut saran tindakan dan rekomendasi adalah dengan melakukan identifikasi control objective serta atributnya yang perlu ditingkatkan, yaitu kematangan saat ini (as-is) lebih rendah dari kematangan yang diharapkan (to be). Jika kematangan Control Objective sudah pada level target atau lebih tinggi, maka Control Objective tidak perlu perbaikan segera, meskipun kematangan beberapa atributnya berada di bawah tingkat kematangan harapan (maturity level to be). Berdasarkan Tabel 4 dan Tabel 5, bahwa semua control objective pada Proses DS10 dan DS11 perlu ditingkatkan. Sedangkan Tabel 6 dan Tabel 7 merupakan langkah tindakan apa yang perlu dilakukan serta rekomendasi yang dibutuhkan untuk meningkatkan kematangan prosesnya.

Dengan menghitung kematangan proses secara horizontal, sehingga dapat merekomendasikan tindakan untuk meningkatkan kematangan proses berdasarkan pada peningkatan Control Objective. Cara rekomendasi ini dimungkinkan oleh sifat preskriptif dari Control Objective. Tindakan peningkatan seperti itu biasanya dirumuskan pada tingkat teknis. Di sisi lain, rekomendasi di tingkat manajemen juga diperlukan untuk memastikan bahwa tindakan dapat dilakukan dengan sukses dalam upaya yang tepat. Rekomendasi untuk manajemen dirumuskan dengan mengelompokkan dan mengabstraksi tindakan serupa. Rekomendasi divalidasi untuk memastikan bahwa rekomendasi yang diberikan sesuai dengan kebutuhan dan kemampuan perusahaan.

\subsection{Validasi}

Untuk rekomendasi yang diperlukan oleh perusahaan/instansi, peneliti telah mengembangkan skala untuk validasi, di mana kemampuan perusahaan didefinisikan dalam tiga kategori, yaitu (1) tidak mampu, (2) mampu dengan upaya besar, dan (3) sepenuhnya mampu. Setiap kategori dapat dibagi lebih rincian. Rekomendasi dan validasi harus dilakukan secara iteratif hingga menghasilkan rekomendasi yang diperlukan dan sesuai dengan kemampuan perusahaan.

Hasil penelitian berdasarkan framework Cobit 4.1 yaitu dengan merumuskan 3 rekomendasi perbaikan, kemudian rekomendasi tersebut selanjutnya dilakukan validasi dengan menggunakan skor seperti pada Tabel 8. Tabel tersebut mencantumkan tiga rekomendasi yang diusulkan, dengan melibatkan 2 orang sebagai responden. Kedua orang tersebut adalah orang yang terlibat didalam pengambilan keputusan. Responden dimintai konfirmasi mengenai usulan rekomendasi berdasarkan Cobit 4.1 apakah bisa diterapkan atau tidak. Jawaban dari responden tersebut dirata-rata dan ditunjukkan pada Tabel 8 yang ada tanda centang $(\sqrt{ })$. Validasi adalah untuk memberiksa tanggapan mengenai usulan rekomendasi yang diberikan apakah dapat dapat diterapkan pada organisasinya, dengan memberikan skor antara 0 sampai 9.

Rekomendasi tidak diperlukan jika (skor $=0$ ). Hasil validasi menunjukkan bahwa semua jawaban kurang berada pada kelompok skor 4 sampai 6, atau pada skor kurang dari 7 sehingga dapat diasumsikan bahwa penerapan rekomendasi berada bawah kapabilitas minimum, untuk mengimplementasikan rekomendasi tersebut harus dengan upaya yang keras, kemudian validasi selanjutnya dengan menanyakan tentang kendala apa yang mungkin menghambat instansi, hasilnya menunjukkan bahwa kendala utama adalah kurangnya personel dengan keahlian yang memadai dalam mengelola data dan mengelola masalah, serta tidak ada anggaran yang memadai yang dialokasikan untuk meningkatkan keahlian personil. 
Tabel 10. Validasi Rekomendasi proses DS10 dan DS11

\begin{tabular}{|c|c|c|c|c|c|c|c|c|c|}
\hline \multirow[t]{2}{*}{ Rekomendasi } & \multirow{2}{*}{$\begin{array}{c}\begin{array}{c}\text { Tidak } \\
\text { dibutuhkan }\end{array} \\
0 \\
\end{array}$} & \multicolumn{3}{|c|}{$\begin{array}{c}\text { Tidak } \\
\text { mampu }\end{array}$} & \multicolumn{3}{|c|}{$\begin{array}{c}\text { Mampu } \\
\text { dengan } \\
\text { usaha keras }\end{array}$} & \multicolumn{2}{|c|}{$\begin{array}{l}\text { Sepenuhnya } \\
\text { mampu }\end{array}$} \\
\hline & & 1 & 2 & 3 & 4 & 5 & 6 & 7 & \\
\hline $\begin{array}{l}\text { Adanya standar kebijakan untuk } \\
\text { mempermudah dalam melakukan prosedur } \\
\text { pengelolaan masalah sehingga instansi } \\
\text { harus menetapkan pihak } \\
\text { penanggungjawab dengan berdasarkan } \\
\text { standar dan kebijakan tersebut dapat } \\
\text { disertai reward \& punishment terhadap } \\
\text { penanganan insiden. }\end{array}$ & & & & & $\sqrt{ }$ & & & & \\
\hline $\begin{array}{l}\text { Instansi harus menetapkan } \\
\text { penanggungjawab dalam pelaporan } \\
\text { manajemen masalah secara formal untuk } \\
\text { memudahkan aktivitas monitoring dan } \\
\text { proses evaluasi kondisi perusahaan. }\end{array}$ & & & & & & $\sqrt{ }$ & & & \\
\hline $\begin{array}{l}\text { Instansi harus menetapkan kebijakan dan } \\
\text { prosedur manajemen data yang formal } \\
\text { seperti aturan khusus / SOP dimana } \\
\text { ketetapan aturan tersebut dapat diterima } \\
\text { oleh seluruh divisi dan berorientasi pada } \\
\text { kondisi sistem pelayanan dimasa depan } \\
\text { yang lebih baik. }\end{array}$ & & & & & & $\sqrt{ }$ & & & \\
\hline
\end{tabular}

\section{KESIMPULAN DAN SARAN}

\subsection{Kesimpulan}

Perhitungan dalam penilaian kematangan proses TI didasarkan pada kematangan Control Objective. Kematangan Control Objective dihitung dari kematangan atribut dari masing-masing Control Objective. Seperti diilustrasikan dalam Tabel 4 untuk Proses DS10 dan Tabel 5 untuk Proses DS11, cara perhitungan ini dilakukan secara horizontal seperti yang ditunjukkan dengan panah di bawah tabel. Hasil penghitungan tingkat kematangan menunjukkan bahwa tingkat kematangan berada pada nilai 2.95 yaitu di level 3. Ada kesenjangan antara tingkat kematangan saat ini (as-is) dan tingkat kematangan yang diharapkan (to be) yaitu level 4. Dengan adanya kesenjangan tersebut, maka diperlukan adanya rekomendasi perbaikan untuk peningkatan nilai kematangan.

Penelitian ini menghasilkan 3 rekomendasi untuk perbaikan peningkatan nilai kematangan, (1) Adanya standar kebijakan akan mempermudah dalam melakukan prosedur pengelolaan masalah sehingga instansi harus menetapkan pihak penanggungjawab serta berdasarkan standar kebijakan tersebut dapat disertai reward \& punishment terhadap penanganan insiden, (2) Instansi harus menetapkan penanggungjawab dalam pelaporan manajemen masalah secara formal untuk memudahkan aktivitas monitoring dan proses evaluasi kondisi perusahaan, (3) Instansi harus menetapkan kebijakan dan prosedur manajemen data yang formal seperti aturan khusus / SOP dimana ketetapan aturan tersebut dapat diterima oleh seluruh divisi dan berorientasi pada kondisi sistem pelayanan dimasa depan yang lebih baik.

Hasil validasai rekomendasi yang diusulkan menunjukkan bahwa instansi/ perusahaan mampu menerapkan rekomendasi tersebut dengan usaha keras. Hal ini ditunjukkan pada skor yang berada di kisaran 4 samapai 6 . 


\subsection{Saran}

Penelitian selanjutnya apabila menggunakan pendekatan ini, peneliti akan menggunakan beberapa domain, agar rekomendasi yang dihasilkan lebih tepat dan valid. Serta menggunakan studi kasus lain dengan domain yang lengkap. Semoga dengan penelitian ini bisa memberikan manfaat bagi pembaca dan peneliti lain.

\section{DAFTAR PUSTAKA}

Dirgahayu, T., \& Setiyowati. (2018). On the improvement of IT process maturity: assessment, recommendation and validation. MATEC Web of Conferences, 154, 1-5. https://doi.org/10.1051/matecconf/201815403017

Fitrianah, D., \& Sucahyo, Y. G. (2008). Audit Sistem Informasi/Teknologi Informasi Dengan Kerangka Kerja Cobit Untuk Evaluasi Manajemen Teknologi Informasi Di Universitas Xyz. Jurnal Sistem Informasi MTI-UI, 4(1), 37-46. https://doi.org/10.21609/jsi.v4i1.243

Gomes, R., \& Ribeiro, J. (2009). the Main Benefits of Cobit in a High Public Educational Institution - a Case Study. In PACIS 2009 Proceedings (pp. 0-11).

Gui, A., Gondodiyoto, S., \& Japari. (2010). EVALUASI SISTEM INFORMASI PENJUALAN PT SPNS Anderes. ComTech, 1(1), 112-120.

Iqbal, M., \& Nieves, M. (2007). ITIL Version 3 Service Strategy. ITL Official Publizer (Vol. 34). https://doi.org/10.1016/j.im.2003.02.002

IT Governance Institute. (2003). Board Briefing on IT Governance (Second edi).

IT Governance Institute. (2007). CobiT 4.1 Framework Control Objectives Management Guidelines Maturity Models. IT Governance Institute. Retrieved from www.isaca.org/cobitfeedback to

Pederiva, A. (2003). The COBIT Maturity Model in a Vendor Evaluation Case. Information Systems Control Journal., 3, 1-4. Retrieved from www.isaca.org.

Tanuwijaya, H., \& Sarno, R. (2010). Comparation of CobiT Maturity Model and Structural Equation Model for Measuring the Alignment between University Academic Regulations and Information Technology Goals. IJCSNS International Journal of Computer Science and Network Security, 10(6), 80-92.

Terttiaavini. (2013). Analisa faktor keberhasilan dalam memanfaatkan Teknologi Informasi pada pelaksanaan eKTP di Kota Palembang. In Seminar Nasional Aplikasi Teknologi Informasi (SNATI) Yogyakarta (pp. 10-15). Yogyakarta.

Walker, A., McBride, T., Basson, G., \& Oakley, R. (2012). ISO/IEC 15504 measurement applied to COBIT process maturity. Benchmarking: An International Journal, 19(2), 159-176. https://doi.org/10.1108/14635771211224518

Wijkström, P. J. M. S. H. (2007). Model-Based It Governance Maturity Assessments With Cobit. In ECIS 2007 Proceedings (pp. 1276-1287). 